\title{
Performance of mini-tomato hybrids in different training systems with different number of stems
}

\author{
Pablo F Vargas ${ }^{1}$; Leonardo S Duarte ${ }^{1}$; Edgard HC Silva ${ }^{2}$; Amanda C Zecchini ${ }^{1}$; Renato S Soares ${ }^{2}$; Leandro \\ JG Godoy ${ }^{1}$
}

${ }^{1}$ Universidade Estadual Paulista(UNESP), Registro-SP, Brasil; pablo@registro.unesp.br; leonardos.duarte@hotmail.com; amandachiarion@ hotmail.com; legodoy@registro.unesp.br; ${ }^{2}$ Universidade Estadual Paulista (UNESP), Jaboticabal-SP, Brasil; edgarddragde@ gmail.com; renato_2366@hotmail.com'

\begin{abstract}
At present, Brazil is among the world's largest tomato producers. This production is directed both for the industry and for fresh consumption. Among the different tomato groups, production of minitomatoes has grown in recent years because of their high commercial value and mainly greater price stability. However, there are few studies investigating the proper management of this group, as it is recent in the country. The aim of the present study was to evaluate the viability of mini-tomato hybrids in different training systems, in greenhouse conditions. The experiment was set as a randomized block design in a $2 \times 2 \times 4$ factorial arrangement with two numbers of stems (one and two stems per plant), two training systems [conventional (vertical) and horizontal], and four hybrids [AF 18196 (Sakata Seed); AF 13106 (Sakata Seed); Nina (Takii Seed) and Cocktail Mascot (Agristar/Top Seed Premium)], with three replicates and four plants per plot in the usable area. The evaluated variables were production per plant, fruit weight, transverse and longitudinal fruit diameter, number of fruits per plant, number of clusters per plant, number of fruits per cluster, precocity, production cycle, chlorophyll index, soluble solids, and crop cycle. The most promising hybrids are AF 13106 (2.71 kg/plant), AF 18196 (2.63 kg/plant) and Mascot (2.38 $\mathrm{kg} /$ plant $)$, managed with two stems $(2.63 \mathrm{~kg} / \mathrm{plant})$, in the vertical system $(2.94 \mathrm{~kg} /$ plant $)$.
\end{abstract}

Keywords: Solanum lycopersicon, tomato management, genotype $\times$ environment interaction.

\section{RESUMO}

Desempenho agronômico de híbridos de minitomate em diferentes sistemas de condução e número de hastes

Atualmente o Brasil configura-se entre os maiores produtores de tomate, sendo tal produção direcionada tanto para a indústria como para mesa. Dentre os diferentes grupos de tomateiro, os minitomates apresentam crescimento de produção nos últimos anos, devido seu alto valor comercial e maior estabilidade de preços no momento da comercialização. Contudo, por ser recente no país, poucos são os estudos com esse grupo. Objetivou-se avaliar híbridos de minitomates em diferentes sistemas de condução, em cultivo protegido. $\mathrm{O}$ delineamento experimental utilizado foi em blocos casualizados, em esquema fatorial $2 \times 2 \times 4$, sendo os fatores: dois números de hastes (uma e duas hastes por planta), dois sistema de condução [convencional (vertical) e horizontal] e quatro híbridos [AF 18196 (Sakata Seed); AF 13106 (Sakata Seed); Nina (Takii Seed); Cocktail Mascot (Agristar/Top Seed Premium)], com três repetições, contendo quatro plantas por parcela na área útil. Avaliou-se a produção por planta, massa do fruto, diâmetro transversal e longitudinal do fruto, número de frutos por planta, número de cachos por planta, número de frutos por cacho, precocidade, ciclo de produção, teor de clorofila, sólidos solúveis e ciclo da cultura. Os híbridos mais promissores são AF 13106 (2,71 kg/planta), AF 18196 (2,63 kg/planta) e Mascot (2,38 $\mathrm{kg} /$ planta), manejado com duas hastes $(2,63 \mathrm{~kg} /$ planta) no sistema vertical de condução $(2,94 \mathrm{~kg} /$ planta $)$.

Palavras-chave: Solanum lycopersicon, manejo do tomateiro, interação genótipo $\times$ ambiente.

\section{Received on April 6, 2016; accepted on January 5, 2017}

$\mathrm{T}$ he tomato is a vegetable of considerable economic importance in the world, as a component of the diet of several cultures. Brazil is a major tomato producer, having produced 4,187,646 t in 2013 (Agrianual, 2016).

The Brazilian tomato production is destined for industrial processing and fresh consumption. Within the latter segment, consumption of cultivars of the Italian and mini-tomato groups has shown a significant rise, mainly because of their organoleptic characteristics.

Since mini-tomatoes were placed on the market in the 1990s, their cultivation and consumption are increasing and spreading across the country. This table tomato is typically consumed raw and has diverse uses; it is even considered a gourmet product, mainly for being present in refined menus (Preczenhak et al., 2014). This type of tomato is also used in the decoration of dishes (Silva et al., 2011).

To meet the growing demand for mini-tomatoes, farmers are increasingly specialized through innovations and improvements in cropping, such as the adoption of different crop management techniques aiming at greater yields (Shirahige et al., 2010).

Several management techniques are available for tomato plants. Different 
strategies, such as training methods or number of stems used, influence tomato growing by changing solar radiation, ventilation, and the efficiency in the control of pests and diseases (Wamser et al., 2007).

Some mini-tomato producers have opted to train plants horizontally, a socalled variation of the 'Italian system' or 'Sicilian system', whose practice is already widespread among European croppers, especially in the region of Almeria, Spain.

There is no obvious interest in producing mini-tomato fruits of large size (Fernandes et al., 2002), as this is a characteristic of this tomato group. Instead, producers are more interested in adopting a system that yields a higher number of small fruits, without compromising the fruit quality.

The training method and the number of stems, together with other cultural practices, have a significant importance in tomato production, since they influence qualitative and quantitative aspects of production and may thus add value to the product (Almeida et al., 2015).

Based on the above considerations, under the hypothesis that different training methods provide greater yields to mini-tomato growing, the present study was conducted to evaluate the agronomic performance of mini-tomato hybrids under different plant training systems and with different numbers of stems.

\section{MATERIAL AND METHODS}

The experiment was conducted at the Vegetable Crops Section of São Paulo State University, Registro, São Paulo State, Brazil (24³2'05'S, $47^{\circ} 51^{\prime} 40^{\prime}$ 'W), in an arch-shaped greenhouse $(4 \mathrm{~m}$ high $\times 7 \mathrm{~m}$ wide $\times 24$ $\mathrm{m}$ long) covered with a light-diffuser agricultural film with $150-\mu$ thick antiUV treatment, and black raffia net with $50 \%$ shading on the sides.

A randomized-block experimental design in a $2 \times 2 \times 4$ factorial arrangement was adopted, with the following factors: number of stems (plants with one or two stems), training systems (vertical and horizontal), and four mini-tomato hybrids [AF 18196 (Sakata Seed); AF 13106 (Sakata Seed); Nina (Takii Seed) and Cocktail Mascot (Agristar/Top Seed Premium)]. Three replicates, containing four plants per plot as usable area, were used.

Seedlings were grown in 162-cell plastic trays filled with the substrate Plantmax HT. One seed was sown per cell. Trays were placed in a greenhouse equipped with a sprinkler irrigation system.

The transplant was performed when the seedlings had four to five true leaves, measuring approximately $11 \mathrm{~cm}$. The spacing used was $1.2 \mathrm{~m}$ between rows and $30 \mathrm{~cm}$ between plants.

The mini-tomatoes were grown in 13-L plastic pots filled with Golden Mix Misto 98 coconut shell fiber with the following physical characteristics: $94 \%$ porosity, $35 \%$ aeration capacity, and $41 \%$ capacity of available water retention. The following chemical characteristics of the substrate were revealed: $\mathrm{pH}=$ 5.1 ; electrical conductivity $=1.0 \mathrm{dS} / \mathrm{m}$; dinitrate $=8.1 \mathrm{mg} / \mathrm{L} ; \mathrm{P}=53.0 \mathrm{mg} / \mathrm{L} ; \mathrm{Cl}=$ $44.6 \mathrm{mg} / \mathrm{L} ; \mathrm{S}=92.1 \mathrm{mg} / \mathrm{L} ;$ ammonium $\mathrm{N}$ $=17.7 \mathrm{mg} / \mathrm{L} ; \mathrm{K}=270.1 \mathrm{mg} / \mathrm{L} ; \mathrm{Na}=12.6$ $\mathrm{mg} / \mathrm{L} ; \mathrm{Ca}=9.9 \mathrm{mg} / \mathrm{L} ; \mathrm{Mg}=6.6 \mathrm{mg} / \mathrm{L} ; \mathrm{B}=$ $0.5 \mathrm{mg} / \mathrm{L} ; \mathrm{Cu}=0.1 \mathrm{mg} / \mathrm{L} ; \mathrm{Fe}=0.4 \mathrm{mg} / \mathrm{L}$; $\mathrm{Mn}=0.1 \mathrm{mg} / \mathrm{L}$; and $\mathrm{Zn}=0.5 \mathrm{mg} / \mathrm{L}$.

Drip irrigation was applied; from the vegetative to the flowering stages, the following nutrient solution was used for every $1,000 \mathrm{~L}$ of water: 0.50 $\mathrm{g}$ calcium nitrate, $0.15 \mathrm{~g}$ potassium nitrate, $0.20 \mathrm{~g}$ potassium sulfate, 0.30 $\mathrm{g}$ magnesium sulfate, $0.20 \mathrm{~g}$ potassium dihydrogen phosphate, $25.0 \mathrm{~g}$ Tenso Cocktail, and 10.0 g Tenso Ferro; electric conductivity was maintained at 1.47 with a K/N ratio of 2.00 . Nutrient solution with the following components was used during the production stage: $0.75 \mathrm{~g}$ calcium nitrate; $0.18 \mathrm{~g}$ potassium nitrate, $0.36 \mathrm{~g}$ potassium sulfate, $0.05 \mathrm{~g}$ monoamonium phosphate, $0.19 \mathrm{~g}$ dihydrogen phosphate, $0.55 \mathrm{~g}$ magnesium sulfate, $0.15 \mathrm{~g}$ potassium chloride, $25.0 \mathrm{~g}$ Tenso Cocktail, and $10.0 \mathrm{~g}$ Tenso Ferro; electric conductivity was maintained at 2.53 with a $\mathrm{K} / \mathrm{N}$ ratio of 2.36 .

A timer was used to control fertigation, started three times a day
(9, 13 and $16 \mathrm{~h})$, during $15 \mathrm{~min}$, with a dripper flow of $80 \mathrm{~mL} / \mathrm{min}$ solution per pot. To prevent salinity of the substrate, approximately $30 \%$ of the solution were drained at each fertigation.

Plants were trained (staked) according to the experimental treatment, conventionally (vertical) or horizontally.

In the conventional system, plants were trained vertically with strapping plastic, fixed on wires near the base of the plant and two meters from the ground. Once the maximum height of the wire was reached, plants were trained vertically, but downwards, preventing strangulation of the stems at the inflection point.

For the horizontal training, once the plants reached $30 \mathrm{~cm}$ high, they were trained horizontally by bending their stem. Upon reaching the limit of the portion of the study, plants were brought back up, and, after growing 30 $\mathrm{cm}$, they were bent again to continue their growth horizontally, and thus until the maximum height of the wire was reached.

Plants were trained with one or two stems, staked individually, and trained with plastic ribbons attached to steel wires at a height of $2 \mathrm{~m}$. For the conventional system, a collator was used to avoid plant lodging and stem breaking. A hook-shaped clip (Cliphook) was used for the plants trained horizontally.

The entire plant management was carried out according to the crop needs and following technical recommendations of the related literature.

Plants were harvested manually, three times a week, when the fruits showed $70 \%$ or more red color. Subsequently, the fruits were packed in plastic boxes and transported to the Vegetable Crops Laboratory of UNESP in Registro, where the following production (yield per plant, number of fruits per plant, fruit weight, number of clusters per plant, number of fruits per cluster, precocity, production cycle, and crop cycle), biometric (transverse and longitudinal fruit diameter), and quality (SPAD chlorophyll content index, and soluble solids) variables were evaluated.

Yield per plant (YP) was obtained by 
weighing all the fruits of each plant using a digital scale with two decimal places (kg/plant). The number of fruits per plant (NFP) was estimated as the total sum of fruits obtained from harvests during the production period. Fruit weight (FW) was calculated as the arithmetic average of the weight of the fruits from the plot ( $g$ ) divided by the number of fruits. Number of clusters per plant (NCP) was obtained by counting all plant trusses. Number of fruits per cluster (NFC) was determined by counting all the fruits of all plant trusses and then calculating the arithmetic average. Precocity (P) was calculated as the difference in days from transplanting to the harvest of the first cluster. Production cycle (PC) was determined as the difference in days between the last and first harvests. Crop cycle (CC) was determined as the number of days from transplanting to the last harvest.

The transverse fruit diameter (TD) and longitudinal fruit diameter (LD) were obtained by sampling five fruits taken at random from each plot, using a digital pachymeter, and then calculating the arithmetic average $(\mathrm{mm})$.

The SPAD chlorophyll content index (TC) was assessed in five leaflets of the leaf opposite to the first given trusses, using a manual digital chlorophyll meter (N-Tester ${ }^{\circledR}$; Yara 2000) with a data logger. The soluble solids content (SS) was determined in five fruits each from the first, fourth, and seventh harvests, which were crushed with a mixer and strained through a colander; an aliquot of the juice was inserted in a digital refractometer, and values were expressed in ${ }^{\circ}$ Brix.

Data were subjected to analysis of variance by the $\mathrm{F}$ test, and means were compared by Tukey's test at 5\% probability, using Sisvar software v. 5.5 (Ferreira, 2011).

\section{RESULTS AND DISCUSSION}

There was no significant triple interaction among the studied factors for any of the traits. An interaction effect between training systems and hybrid was detected for fruits weight (FW) and number of fruits per cluster (NFC); number of stems and hybrids for $\mathrm{FW}, \mathrm{NFC}$, precocity $(\mathrm{P})$, and production cycle (PC); and number of stems and type of training for the number of clusters per plant (NCP) and longitudinal fruit diameter (LD).

When the tomatoes were grown with two stems $(2.63 \mathrm{~kg} /$ plant $)$, the YP was higher compared with plants with one stem (2.25 kg/plant). Training with two stems also provided greater values for NFP (420.28 fruits/plant) and SS (6.64 ${ }^{\circ}$ Brix) (Table 1).

The higher YP and NFP values in plants with two stems can be explained by the greater flower production, increased photosynthetic area, and more clusters per plant that consequently led to a larger number of fruits. These results corroborate Carvalho \& Tessarioli Neto (2005), Charlo et al. (2009), and Takahashi \& Cardoso (2015).

TD was higher in plants with one stem $(33.83 \mathrm{~mm})$ than in those with two stems $(32.12 \mathrm{~mm})$.

A higher soluble solids content (SS, ${ }^{\circ}$ Brix) was observed in plants grown with two stems, suggesting that the smaller size of the fruits in the treatments trained with two stems contributed to the increase in soluble solids, due to their concentration in fruits. Hanson et al. (2004) reported that there is a negative correlation between fruit size and soluble solids content in tomato fruits.

Table 1. Average values of the variables production per plant (PP), number of fruits per plant (NFP), transversal fruit diameter (DT), soluble solids (SS), pH, chlorophyll index (TC) and crop cycle (CC) analyzed in function of different hybrids, training systems and number of stems. Registro, UNESP, 2016.

\begin{tabular}{|c|c|c|c|c|c|c|c|}
\hline Factors/treatments & PP (kg/plant) & NFP & DT $(\mathrm{mm})$ & SS ( ${ }^{\circ}$ Brix $)$ & pH & TC (SPAD) & CC (days) \\
\hline \multicolumn{8}{|l|}{ Stems $\left(n^{0}\right)$} \\
\hline$\overline{1}$ & $2.25 \mathrm{~b}^{1}$ & $287.05 \mathrm{~b}$ & $33.82 \mathrm{a}$ & $6.45 \mathrm{~b}$ & $4.28 \mathrm{a}$ & $40.33 \mathrm{a}$ & $182.00 \mathrm{a}$ \\
\hline 2 & $2.63 \mathrm{a}$ & $420.28 \mathrm{a}$ & $32.12 \mathrm{~b}$ & $6.64 \mathrm{a}$ & $4.26 \mathrm{a}$ & $40.59 \mathrm{a}$ & $181.41 \mathrm{a}$ \\
\hline F & $11.95^{* *}$ & $68.86^{* *}$ & $12.26^{* *}$ & $4.6^{*}$ & $0.53^{\text {ns }}$ & $0.15^{\text {ns }}$ & $1.00^{\mathrm{ns}}$ \\
\hline \multicolumn{8}{|l|}{ Training system } \\
\hline Horizontal & $1.96 \mathrm{~b}$ & $350.64 \mathrm{a}$ & $31.72 \mathrm{~b}$ & $6.31 \mathrm{~b}$ & $4.29 \mathrm{a}$ & $40.34 \mathrm{a}$ & $182.00 \mathrm{a}$ \\
\hline Vertical & $2.94 \mathrm{a}$ & $356.69 \mathrm{a}$ & $34.22 \mathrm{a}$ & $6.78 \mathrm{a}$ & $4.25 \mathrm{a}$ & $40.58 \mathrm{a}$ & $181.41 \mathrm{a}$ \\
\hline F & $75.48^{* *}$ & $0.14^{\mathrm{ns}}$ & $26.78^{* *}$ & $30.21 * *$ & $1.65^{\mathrm{ns}}$ & $0.12^{\mathrm{ns}}$ & $1.00^{\mathrm{ns}}$ \\
\hline \multicolumn{8}{|l|}{ Hybrids } \\
\hline AF 13106 & $2.71 \mathrm{a}$ & $467.11 \mathrm{a}$ & $32.51 \mathrm{~b}$ & $6.43 \mathrm{~b}$ & $4.29 \mathrm{a}$ & $42.97 \mathrm{a}$ & $182.00 \mathrm{a}$ \\
\hline AF 18196 & $2.63 \mathrm{a}$ & $386.45 \mathrm{~b}$ & $32.56 \mathrm{~b}$ & $6.36 \mathrm{~b}$ & $4.30 \mathrm{a}$ & $41.92 \mathrm{ab}$ & $182.00 \mathrm{a}$ \\
\hline Nina & $2.04 \mathrm{~b}$ & $198.46 \mathrm{c}$ & $35.14 \mathrm{a}$ & $6.59 \mathrm{ab}$ & $4.27 \mathrm{a}$ & $40.11 \mathrm{~b}$ & $180.83 \mathrm{a}$ \\
\hline Mascot & $2.38 \mathrm{ab}$ & $362.64 \mathrm{~b}$ & $31.47 \mathrm{~b}$ & $6.80 \mathrm{a}$ & $4.22 \mathrm{a}$ & $36.85 \mathrm{c}$ & $182.00 \mathrm{a}$ \\
\hline $\bar{F}$ & $7.32 * *$ & $49.28 * *$ & $10.27 * *$ & $5.14 * *$ & $1.44^{\mathrm{ns}}$ & $15.36^{* *}$ & $1.00^{\mathrm{ns}}$ \\
\hline $\mathrm{CV}(\%)$ & 15.69 & 15.73 & 5.08 & 4.55 & 2.55 & 5.85 & 1.11 \\
\hline
\end{tabular}

$* *, *$ and ${ }^{\text {ns. }}$ significant at $1 \%, 5 \%$ and not significant by $\mathrm{F}$ test, respectively. ${ }^{1}$ averages followed by the same letter, within each factor, in the column do not differ by Tukey test at $5 \%$ probability. 
Table 2. Average values of the variables number of fruits per cluster (NFC), number of clusters per plant (NCP), longitudinal fruit diameter (DL), precocity $(\mathrm{P})$ and production cycle (CP) analyzed on the basis of different hybrids, training systems and number of stems which had some interaction between factors. Registro, UNESP, 2016.

\begin{tabular}{lccccc}
\hline Factors/treatments & NFC & NCP & DL $(\mathbf{m m})$ & P (days) & CP (days) \\
\hline Number of stems & & & & & \\
\hline 1 & $21.89^{1} \mathrm{a}$ & $\#$ & $\#$ & $\#$ & $\#$ \\
2 & $18.28 \mathrm{~b}$ & $\#$ & $\#$ & $\#$ & $\#$ \\
\hline F & $50.10^{* *}$ & - & - & - & - \\
\hline Training system & & & & & \\
\hline Horizontal & $\#$ & $\#$ & $\#$ & $89.33 \mathrm{a}$ & $92.83 \mathrm{a}$ \\
Vertical & $\#$ & $\#$ & $\#$ & $87.33 \mathrm{a}$ & $94.95 \mathrm{a}$ \\
\hline F & - & - & - & $1.77^{\mathrm{ns}}$ & $1.77^{\mathrm{ns}}$ \\
\hline Hybrids & & & & & \\
\hline AF 13106 & $\#$ & $18.33 \mathrm{ab}$ & $23.53 \mathrm{c}$ & $\#$ & $\#$ \\
AF 18196 & $\#$ & $20.29 \mathrm{a}$ & $24.79 \mathrm{~b}$ & $\#$ & $\#$ \\
Nina & $\#$ & $15.97 \mathrm{c}$ & $30.72 \mathrm{a}$ & $\#$ & $\#$ \\
Mascot & $\#$ & $18.09 \mathrm{bc}$ & $25.20 \mathrm{~b}$ & $\#$ & $\#$ \\
\hline F & - & $9.72^{* *}$ & $194.56^{* *}$ & - & - \\
CV $(\%)$ & 8.79 & 10.78 & 3.04 & 5.88 & 5.88 \\
\hline
\end{tabular}

$* *, *$ and ${ }^{\mathrm{ns}}$ : significant at $1 \%, 5 \%$ and not significant by $\mathrm{F}$ test, respectively. ${ }^{1}$ averages followed by the same letter, within each factor, in the column do not differ by Tukey test at $5 \%$ probability. \# interaction between two factors.

No difference was found for $\mathrm{pH}$, SPAD chlorophyll content index (TC), or production cycle with the different numbers of stems. Charlo et al. (2009) evaluated numbers of stems for tomato and found no significant differences in $\mathrm{pH}$.

Between the two training systems, plants trained vertically showed higher average production values, producing $2.94 \mathrm{~kg} /$ plant $(81 \mathrm{t} / \mathrm{ha})$ of tomatoes, a $50 \%$ higher yield compared with the horizontal system $(1.96 \mathrm{~kg} / \mathrm{plant})$. In the vertical system, higher values were also observed for transversal fruit diameter $(\mathrm{mm})$ and soluble solids ( ${ }^{\circ}$ Brix).

No difference was found for NFP, with 356.69 fruits/plant for the vertical system and 350.64 fruits/plant for the horizontal system. It thus appears that tomato plants do not lose the ability to produce fruit when trained horizontally. However, there was a considerable decrease in fruit size and weight, as observed by YP and TD.

The vertical training system provides greater photosynthetic efficiency, as it improves the solar radiation and increases ventilation (Santos et al., 1999; Wamser et al., 2008). The therefore have smaller dimensions, which are features related to the genetic background of the cultivars (Table 2).

A higher value for SS was observed in 'Mascot' $\left(6.8^{\circ}\right.$ Brix $)$, which did not differ from Nina $\left(6.59^{\circ}\right.$ Brix). Hybrids AF 13106 and AF 18196 showed lower soluble solids values (6.43 and $6.36^{\circ}$ Brix, respectively), but did not differ from 'Nina'.

Despite the statistical differences found in soluble solids for the factors number of stems and type of training and hybrids, it is noteworthy that the amplitudes found would hardly be noticeable to consumers, thus having no practical nature.

The hybrids did not differ with respect to $\mathrm{pH}$. The average values $\mathrm{pH}$ are within the range considered ideal for good-quality tomatoes and close to those found by Guilherme et al. (2014), who obtained $\mathrm{pH}$ values below 4.5 in three cherry tomato genotypes. Although lower $\mathrm{pH}$ values generate more-sour fruit, this characteristic provides a longer preservation of the fruit postharvest (Nascimento et al., 2013).

Hybrid AF 13106 had the highest value for SPAD index (42.97), higher than hybrids Nina and Mascot, but did not differ from AF 18196. Hybrids AF 18196 and Nina did not differ from each other. Mascot had the lowest average (36.85). These values are related to the genetic characteristics of each hybrid, since they are from different companies, which work with different gene banks, which may have a higher or lower chlorophyll content.

As for the other factors, there was no difference between hybrids for $\mathrm{CC}$, with an average cycle of 181.7 days.

There were more fruits per cluster (NFC) when plants were trained with only one stem (21.89) compared with two stems (18.28).

For precocity and production cycle, there were no significant differences between the training systems (Table 2 ); thus, on average, the first harvest was performed at 88.33 days, with a production cycle of 93.89 days.

When the number of NCP was analyzed (Table 2), there was a significant difference between hybrids, 
Table 3. Interaction between two factors. training system and hybrids for fruit mass (MF) and number of fruits per cluster (NFC); number of stems and hybrids for fruit mass (MF). precocity $(\mathrm{P})$ and production cycle (CP); and. type of training and number of stems for number of cluster per plant (NCP) and longitudinal fruit diameter (DL). Registro. UNESP. 2015.

\begin{tabular}{|c|c|c|c|c|c|c|}
\hline \multirow{3}{*}{ Hybrids } & \multicolumn{6}{|c|}{ Training system } \\
\hline & \multicolumn{3}{|c|}{ MF (g) } & \multicolumn{3}{|c|}{ NFC } \\
\hline & \multicolumn{2}{|c|}{ Horizontal } & Vertical & Horizontal & \multicolumn{2}{|c|}{ Vertical } \\
\hline AF 13106 & \multicolumn{2}{|c|}{$4.86^{1} \mathrm{bB}$} & $7.16 \mathrm{bA}$ & $23.27 \mathrm{aB}$ & \multicolumn{2}{|c|}{$29.15 \mathrm{aA}$} \\
\hline AF 18196 & \multicolumn{2}{|c|}{$5.58 \mathrm{bB}$} & $8.31 \mathrm{bA}$ & $17.51 \mathrm{bB}$ & \multicolumn{2}{|c|}{$22.51 \mathrm{cA}$} \\
\hline Nina & \multicolumn{2}{|c|}{$8.40 \mathrm{aB}$} & $13.08 \mathrm{aA}$ & $11.52 \mathrm{cB}$ & \multicolumn{2}{|c|}{$14.10 \mathrm{dA}$} \\
\hline Mascot & \multicolumn{2}{|c|}{$5.58 \mathrm{bB}$} & $7.67 \mathrm{bA}$ & $17.34 \mathrm{bB}$ & \multicolumn{2}{|c|}{$25.30 \mathrm{bA}$} \\
\hline $\mathrm{F}$ & \multicolumn{3}{|c|}{$5.61 * *$} & \multicolumn{3}{|c|}{$4.76^{* *}$} \\
\hline $\mathrm{CV}(\%)$ & \multicolumn{3}{|c|}{12.01} & \multicolumn{3}{|c|}{8.79} \\
\hline \multirow{3}{*}{ Hybrids } & \multicolumn{6}{|c|}{ Number of stems } \\
\hline & \multicolumn{2}{|c|}{ MF (g) } & \multicolumn{2}{|c|}{ P (days) } & \multicolumn{2}{|c|}{ CP (days) } \\
\hline & 1 & 2 & 1 & 2 & 1 & 2 \\
\hline AF 13106 & $6.85^{1} \mathrm{bA}$ & $5.16 \mathrm{bB}$ & $76.00 \mathrm{bB}$ & $86.66 \mathrm{aA}$ & $107.00 \mathrm{aA}$ & $95.66 \mathrm{aB}$ \\
\hline AF 18196 & $7.78 \mathrm{bA}$ & $6.10 \mathrm{bB}$ & $92.00 \mathrm{aA}$ & $89.33 \mathrm{aA}$ & $90.00 \mathrm{bA}$ & $92.83 \mathrm{aA}$ \\
\hline Nina & $12.12 \mathrm{aA}$ & $9.36 \mathrm{aB}$ & $92.00 \mathrm{aA}$ & $92.00 \mathrm{aA}$ & $90.00 \mathrm{bA}$ & $90.00 \mathrm{aA}$ \\
\hline Mascot & $6.85 \mathrm{bA}$ & $6.40 \mathrm{bA}$ & $89.33 \mathrm{aA}$ & $89.33 \mathrm{aA}$ & $92.83 \mathrm{bA}$ & $92.83 \mathrm{aA}$ \\
\hline $\mathrm{F}$ & 3.2 & & & & 3.88 & \\
\hline $\mathrm{CV}(\%)$ & 12. & & & & 5.8 & \\
\hline & & & $\mathrm{NuI}$ & ems & & \\
\hline Training & & $\mathrm{NC}$ & & & $(\mathrm{mm})$ & \\
\hline & 1 & & 2 & 1 & & 2 \\
\hline Horizontal & $14.81^{1}$ & & $26.31 \mathrm{aA}$ & $26.24 \mathrm{aA}$ & & $.00 \mathrm{bB}$ \\
\hline Vertical & 11.56 & & $20.01 \mathrm{bA}$ & $26.65 \mathrm{aA}$ & & $.35 \mathrm{aA}$ \\
\hline $\bar{F}$ & & 7.26 & & & $25^{*}$ & \\
\hline $\mathrm{CV}(\%)$ & & 10.7 & & & .04 & \\
\hline
\end{tabular}

**. $*$ and ${ }^{\text {ns: }}$ significant at $1 \% .5 \%$ and not significant by $\mathrm{F}$ test. respectively. ${ }^{1}$ averages followed by the same letter. within each factor. in the column do not differ by Tukey test at $5 \%$ probability.

with hybrid AF 18196 presenting the highest value (20.29 clusters/plant), but not differing from AF 13106. Hybrid Nina had the lowest NCP (15.97). This variable is an important characteristic in the production of mini-tomatoes, since the hybrids with the highest number of clusters are those which also showed higher productions.

For LD, Nina showed the highest value (Table 2), obtaining fruits with $30.72 \mathrm{~mm}$, larger than the other hybrids. As mentioned previously, Nina has a characteristic fruit of larger caliber due to its genetic attributes.

All hybrids had higher FW values when subjected to the conventional training system, Nina being superior in both types of training, with $8.4 \mathrm{~g}$ and $13.08 \mathrm{~g}$ for the horizontal and vertical strategies, respectively (Table
3). Hybrids AF 13106, AF 18196, and Mascot did not differ within each training system.

For NFC, hybrid AF 13106, in both horizontal and vertical systems, had the highest number of fruits per cluster, averaging 23.27 and 29.15 , respectively. Comparing the training methods, a higher NFC was observed in the vertical system (Table 3 ). The vertical system is inferred to provide the best conditions for plant growth, resulting in a higher number of flowers per cluster and/or better pollination of flowers.

Mascot and AF 18196 did not differ in the horizontal training system. However, in the vertical system, hybrid Mascot produced more fruits per cluster than AF 18196. Nina had the poorest performance for NFC, in both training systems.
An interaction was observed between the factors hybrids and number of stems for FW, P, and PC (Table 3). For FW, except for Mascot, hybrids trained with one stem produced heavier fruits compared to plants with two stems. This is because plants with one stem produced a lower NFP, which allowed for a greater development of the fruit, because of the source/drain ratio. Charlo et al. (2009) also observed this result, in which the fresh weight of the fruits of plants with one stem were higher than that of fruits from plants with two stems, due to fewer clusters.

Hybrid Nina had the highest average FW of the hybrids, both when trained with one (12.12 g) and two (9.36 g) stems. This can be explained by the fact that Nina belongs to the group of cherrytype mini-tomatoes, which have larger 
fruits than grape-type genotypes. None of the other hybrids differed from each other when cropped with one or two stems (Table 3).

Despite being more precocious when trained with one stem, hybrid AF 13106 showed a longer production cycle (107 days), when cropped in the same condition. No effect was observed for the other hybrids within the two numbers of stems studied.

There was an interaction between number of stems and training systems for NCP and LD. Plants with two stems in the horizontal system had a higher number of clusters, producing 26.31 units per plant. The mini-tomatoes trained horizontally had more space to develop, with longer stems than plants trained vertically; additionally, it should be noted the growth habit of the hybrids is indeterminate, so there is constant cluster emission.

The increase in NCP and NFC and reduction of $\mathrm{FW}$ were caused by the higher number of inflorescences and increased competition for photoassimilates, respectively, as found by Carvalho \& Tessariolo Neto (2005) and Mueller \& Wamser (2009).

For LD, plants trained in the horizontal system with one stem had larger fruits compared with plants with two stems. However, plants with two stems showed no significant differences when grown in the vertical or horizontal system.

When trained with one stem, greater light interception is achieved, resulting in higher photosynthetic efficiency (Ambroszczyk et al., 2008; Makobo et al., 2011).

Although plants with two stems present a higher total yield, their average fruit weight appears to be lower (Hesami et al., 2012). For mini-tomatoes, this is not an undesirable effect, since the market prefers small fruits.

With one stem, the competition among plants for water and nutrients and the number of drains (fruits) per plant decreases (Carvalho \& Tessarioli
Neto, 2005; Wamser et al., 2007; Charlo et al., 2009).

Considering the conditions under which this study was carried out, it is concluded that the most promising mini-tomato hybrids are AF 13106, AF 18196, and Mascot, trained with two stems in the conventional system.

\section{ACKNOWLEDGMENTS}

The authors thank the Foundation of Research Support of the State of São Paulo (FAPESP) for the Scientific Research fellowship granted to the second author (case no. 2014/00595-7).

\section{REFERENCES}

AGRIANUAL. 2016: Anuário da agricultura brasileira. São Paulo: FNP Consultoria \& Comércio.

ALMEIDA, VS; SILVA, DJH; GOMES, CN; ANTONIO, AC; MOURA, AD; LIMA, ALR. 2015. Sistema Viçosa para o cultivo de tomateiro. Horticultura Brasileira 33:74-79.

AMBROSZCZYK, AM; CEBULA, S; SEKARA, A. 2008. The effect of plant pruning on the light conditions and vegetative development of eggplant (Solanum melongena) in greenhouse cultivation. Vegetable Crops Research Bulletin 68: $57-70$

CARVALHO, LA; TESSARIOLI NETO, J. 2005. Produtividade de tomate em ambiente protegido, em função do espaçamento e número de ramos por planta. Horticultura Brasileira 23: 986-989.

CHARLO, HCO; SOUZA, SC; CASTOLDI, R; BRAZ, LT. 2009. Desempenho e qualidade de frutos de tomateiro em cultivo protegido com diferentes números de hastes. Horticultura Brasileira 27: 144-149.

FERNANDES, AA.; MARTINEZ, HEP FONTES, PCR. 2002. Produtividade, qualidade dos frutos e estado nutricional do tomateiro tipo longa vida conduzido com um cacho, em sistema hidropônico, em função das fontes de nutrientes. Horticultura Brasileira 20: $275-278$.

FERREIRA, DF. 2011. Sisvar: a computer statistical analysis system. Ciência $e$ Agrotecnologia 35: 1039-1042.

GUILHERME, DO; PINHO, L; CAVALCANTI, TFMO; COSTA, CA; ALMEIDA, AC. 2014 Análise sensorial e físico-química de frutos tomate cereja orgânicos. Revista Caatinga 27: $81-186$

HANSON, PM; YANG, R; WU, J; CHEN, J;
LEDESMA, D; TSOU, SCS. 2004. Variation for antioxidant activity and antioxidants in tomato. Journal of American Society for Horticultural Science 129: 704-711.

HESAMI, A; KHORAMI SS; HOSSEINI, SS. 2012. Effect of shoot pruning and flower thinning on quality and quantity of semi-determinate tomato (Lycopersicon esculentum). Notulae Scientia Biologicae 4: 108-111.

LOOMIS, RS; AMTHOR, JS. 1999. Yield potential, plant assimilatory capacity, and metabolic efficiencies. Crop Science 39: 1584-1596.

MABOKO, MM; PLOOY, CP; CHILOANE, S. 2011. Effect of plant population, fruit and stem pruning on yield and quality of hydroponically grown tomato. African Journal of Agricultural Research 6: 5144-5148.

MUELLER, S; WAMSER, AF. 2009. Combinação da altura de desponte e do espaçamento entre plantas de tomate. Horticultura Brasileira 27: 64-69.

NASCIMENTO, AR; SOARES JÚNIOR, MS; CALIARI, M; FERNANDES, PM; RODRIGUES, JPM; CARVALHO, WT. 2013. Qualidade de tomates de mesa cultivados em sistema orgânico e convencional no estado de Goiás. Horticultura Brasileira 31: 628-635.

PRECZENHAK, AP; RESENDE, JTV; CHAGAS, RR; SILVA, PR; SCHWARZ, K; MORALES, RGF. 2014. Caracterização agronômica de genótipos de minitomate. Horticultura Brasileira 32: 348-356.

SANTOS, HS; PERIN, WH; TITATO, LG; VIDA, JB; CALLEGARI, O. 1999. Avaliação de sistemas de condução em relação à severidade de doenças e à produção de tomateiro. Acta Scientiarum 21: 453-457.

SHIRAHIGE, FH; MELO, AMT; PURQUERIO, LFV; CARVALHO, CRL; MELO, PCT. 2010. Produtividade e qualidade de tomates Santa Cruz e Italiano em função do raleio de frutos. Horticultura Brasileira 28: 292-298.

SILVA, AC; COSTA, CA; SAMPAIO, RA; MARTINS, ER. 2011. Avaliação de linhagens de tomate cereja tolerantes ao calor sob sistema orgânico de produção. Revista Caatinga 24: 33-40.

TAKAHASHI, K; CARDOSO, AII. 2015. Produção e qualidade de mini tomate em sistema orgânico com dois tipos de condução de hastes e poda apical. Horticultura Brasileira 33: 515-520.

WAMSER, AF; MUELLER, S; BECKER, WF; SANTOS, JP. 2007. Produção do tomateiro em função dos sistemas de condução de plantas. Horticultura Brasileira 25: 238-243.

WAMSER, AF; BECKER, WF; SANTOS, JP; MUELLER, S. 2008. Influência do sistema de condução do tomateiro sobre a incidência de doenças e insetos-praga. Horticultura Brasileira 26: 180-185. 